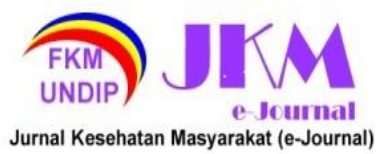

JURNAL KESEHATAN MASYARAKAT (e-Journal)

Volume 9, Nomor 6, November 2021

ISSN: 2715-5617 / e-ISSN: 2356-3346

http://ejournal3.undip.ac.id/index.php/jkm

\title{
FAKTOR LINGKUNGAN FISIK YANG BERHUBUNGAN DENGAN INDEKS PINJAL KHUSUS DI WILAYAH FOKUS PES (STUDI DI DUSUN SUROROWO, KABUPATEN PASURUAN TAHUN 2018)
}

\author{
Desy Hafidhotul IImi ${ }^{1 *}$, Retno Hestiningsih ${ }^{2}$, Nissa Kussariana ${ }^{2}$, Lintang Dian Saraswati ${ }^{2}$ \\ ${ }^{1}$ Peminatan Epidemiologi dan Penyakit Tropik, Fakultas Kesehatan Masyarakat, Universitas Diponegoro, \\ JI. Prof. H. Soedarto, S.H.,Tembalang, Semarang, Indonesia \\ ${ }^{2}$ Bagian Epidemiologi dan Penyakit Tropik, Fakultas Kesehatan Masyarakat, Universitas Diponegoro, Jl. \\ Prof. H. Soedarto, S.H.,Tembalang, Semarang, Indonesia \\ ${ }^{*}$ Corresponding author: desyilmi2112@gmail.com
}

\begin{abstract}
Surorowo hamlet in Kalikebek Village, Tutur Subdistrict, Pasuruan Regency, is one of the focus area of plague that has been monitored by the goverment, as an effort to ensure zero deaths of plague. The monitoring results of the specific flea index in 2017 show a fairly high frequency $(\geq 1)$, which was obtained by calculating the number of Xenopsylla cheopis per number of trap success. This is an indicator that there is still a risk of plague. The purpose of this study is to analyze the physical environmental factors related to the specific flea index in focus area of plague, Surorowo Hamlet. This type of research is analytic observational research with a cross sectional approach. The population in this study were 60 houses that had traps installed by Zoonosis Laboratory field officers to monitor trap success and flea index in the house. The sampling technique used total sampling so that the number of samples was the same as the population, as many as 60 houses. The results showed that there are 4 physical enviromental variables related to the specific flea index, namely the type of house walls $(p=0,0)$, the existance of windows $(p=0,0)$, the existance of ceiling $(p=0,0)$, and the temperature level $(p=0,01)$. Based on the results of this study, to reduce the risk of the high specific flea index in Surorowo Hamlet, the community need to reduce the cavities in the walls that can be a place to live and a path for rats. In addition, it is necessary to procure windows to ensure good lighting and humidity in the house, and reducing wooden dividers on the ceiling of the house so that it does not become a path for rats.
\end{abstract}

Keyword : Physical environment, Specific flea index, Plague

\section{PENDAHULUAN}

Pes merupakan penyakit zoonosis yang disebabkan oleh bakteri Yersinia pestis dan sebagian besar terjadi pada hewan pengerat, khususnya tikus. Pes dapat ditularkan ke manusia melalui gigitan pinjal, khususnya Xenopsyiella cheopis. ${ }^{1}$ Pes termasuk dalam penyakit karantina internasional dan dikategorikan dalam International Health Regulation (IHR) sebagai penyakit yang dapat terulang kembali dan berpotensi menimbulkan Kejadian Luar Biasa $(\mathrm{KLB}) .^{2}$

Di Indonesia, sebanyak 7 kasus dilaporkan pada tahun 2004, 11 kasus pada tahun 2005, 4 kasus pada tahun 2006, dan 82 kasus dilaporkan sebagai kejadian luar biasa (KLB) di Kabupaten Pasuruan pada tahun 2007. ${ }^{3}$ Berdasarkan riwayat kejadian luar biasa Pes, Indonesia menetapkan empat provinsi sebagai wilayah pengawasan yang terletak di Cangkringan di Kabupaten Sleman (Daerah Istimewa Yogyakarta), Kecamatan Selo dan Cepogo di Boyolali (Jawa Tengah),
Ciwidey di Kabupaten Bandung (Jawa Barat), dan di Kecamatan Tutur, Tosari, Puspo, Pasrepan, Kabupaten Pasuruan (Jawa Timur) ${ }^{4}$ Pemerintah kemudian membagi wilayah pengamatan menjadi tiga, salah satunya merupakan daerah fokus Pes. Daerah fokus Pes merupakan desa/dusun/RW tempat ditemukannya Yersinia pestis pada hewan pengerat, manusia, pinjal, tanah, maupun bahan organik. ${ }^{3}$

Dalam kegiatan penekanan kepadatan tikus dan pinjal untuk mencegah risiko terjadinya pes, Dusun Surorowo di Kecamatan Tutur, Kabupaten Pasuruan merupakan salah satu wilayah fokus Pes yang masih rutin dilakukan surveilans. Surveilans dilakukan satu kali dalam satu bulan selama 5 hari berturut-turut. ${ }^{3} \quad$ Pengawasan tersebut dilakukan dalam upaya agar kematian akibat Pes tetap nol. Semakin banyak hasil tangkap tikus di suatu wilayah, maka kemungkinan ditemukannya pinjal juga semakin besar.

Hal penting yang menentukan pengaruh pinjal terhadap risiko penularan Pes 


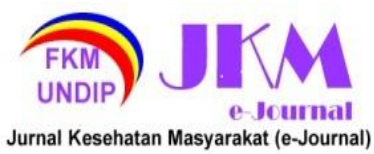

yakni kepadatannya. Kepadatan pinjal diukur melalui dua indikator, yaitu Indesk Pinjal Umum (IPU) dan Indeks Pinjal Khusus (IPK). IPU digunakan untuk mengukur kepadatan pinjal yang bukan merupakan vektor utama penyakit Pes (contoh: Stivalius cognatus). Sedangkan IPK digunakan untuk mengukur kepadatan pinjal Xenopsyiella cheopis selaku vektor utama penyakit Pes. Keberadaan pinjal tersebut, khususnya IPK, kemudian dikendalikan untuk mencegah munculnya kembali Kejadian Luar Biasa Pes. ${ }^{4}$

Hasil pemantauan indeks pinjal khusus di Dusun Surorowo pada Januari sampai Februari 2017 menunjukkan frekuensi yang cukup tinggi, melebihi batas aman, yakni sebesar $\geq 1 .{ }^{5}$ Tingginya indeks pinjal khusus di Dusun Surorowo menunjukkan kerawanan pada gigitan vektor Pes, yang dapat berakibat pada meningkatnya risiko penyakit Pes. Keadaan lingkungan merupakan faktor penting dalam peningkatan risiko terjadinya penyakit Pes, termasuk dalam dinamika indeks pinjal khusus di wilayah pengamatan. Oleh karena itu, untuk mengantisipasi peningkatan risiko tersebut, perlu diketahui faktor-faktor yang berhubungan dengan tingginya indeks pinjal.

Tujuan dari penelitian ini adalah menganalisis faktor-faktor lingkungan fisik yang berhubungan dengan indeks pinjal khusus di Dusun Surorowo, Desa Kalikebek, Kecamatan Tutur, Kabupaten Pasuruan, Jawa Timur pada tahun 2018.

\section{METODE PENELITIAN}

Penelitian ini merupakan penelitian observasional analitik, menggunakan rancangan penelitian cross sectional untuk menjelaskan faktor lingkungan fisik yang berhubungan dengan indeks pinjal khusus. Populasi studi dalam penelitian ini yaitu 60 rumah di Dusun Surorowo yang dipasang trap oleh petugas lapangan Laboratorium Zoonosis untuk memantau trap success dan indeks pinjal di rumah tersebut. Sedangkan sampel dalam penelitian ini diambil menggunakan total sampling sehingga jumlah sampel sama dengan populasi, yakni 60 rumah. Responden dalam penelitian ini merupakan anggota dari rumah yang dipasang trap.

Variabel bebas yang diukur meliputi jenis dinding rumah, keberadaan jendela, keberadaan langit-langit (berupa plafon), jenis lantai, keberadaan ventilasi, kondisi pembuangan sampah, kondisi saluran air, penyimpanan makanan, pencahayaan, suhu, dan kelembaban rumah. Sedangkan variabel terikat yang diukur yakni indeks pinjal khusus (dengan batas tidak aman $\geq 1$ ) yang didapatkan melalui perhitungan jumlah tangkapan Xenopsylla cheopis per jumlah tikus yang tertangkap (trap success). Data variabel terikat didapatkan dari data lapangan Laboratorium Terpadu Zoonosis Nongkojajar Maret-Agustus 2018. Data dalam penelitian kemudian dianalisa secara univariat dan bivariat dengan menggunakan crosstab.

\section{HASIL DAN PEMBAHASAN}

Berdasarkan penelitian yang telah dilakukan melalui wawancara responden dan observasi lingkungan pada 60 rumah, didapatkan hasil penelitian sebagai berikut:

\section{Karakteristik Responden}

Tabel 1. Distribusi Frekuensi Karakteristik Responden

\begin{tabular}{lcl}
\hline $\begin{array}{l}\text { Karakteristik } \\
(\mathbf{n}=6 \mathbf{6})\end{array}$ & Frekuensi & $\%$ \\
\hline Usia & & \\
15-24 tahun & 3 & 5,0 \\
$.25-34$ tahun & 22 & 36,7 \\
35-44 tahun & 20 & 33,3 \\
45-54 tahun & 10 & 16,7 \\
55-64 tahun & 4 & 6,7 \\
$\geq 65$ tahun & 1 & 1,6 \\
\hline & & 100,0 \\
\hline Jenis Kelamin & & \\
. Laki-laki & 10 & 16,7 \\
Perempuan & 50 & 83,3 \\
\hline & & 100,0 \\
\hline Tingkat Pendidikan & & \\
Tidak tamat SD & 3 & 5,0 \\
Tamat SD & 41 & 68,3 \\
Tamat SMP & 8 & 13,3 \\
Tamat SMA & 1 & 1,7 \\
Tidak sekolah & 7 & 11,7 \\
\hline & & 100,0 \\
\hline
\end{tabular}

Jenis Pekerjaan

$\begin{array}{lll}\text {. Ibu Rumah Tangga } \quad 1 & 1,7\end{array}$

\begin{tabular}{lll}
. Pekebun & $59 \quad 98,3$ \\
\hline
\end{tabular}

Berdasarkan tabel 1, diketahui

responden paling banyak berasal dari kelompok usia 25-34 tahun, dengan rata-rata usia 37,8 tahun. Usia paling muda yaitu 21 tahun dan paling tua 65 tahun. Berdasarkan jenis kelamin, sebagian besar responden yaitu perempuan. Selain itu, pendidikan sebagian besar responden merupakan tamatan SD. Dan berdasarkan pekerjaan, hampir seluruh responden bekerja sebagai pekebun apel. 


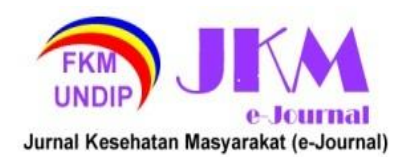

Distribusi Frekuensi Indeks Pinjal Khusus Tabel 2. Distribusi Frekuensi Indeks Pinjal Khusus

\begin{tabular}{lrl}
\hline $\begin{array}{l}\text { Indeks Pinjal Khusus } \\
(\mathbf{n}=\mathbf{6 0})\end{array}$ & Frekuensi & $\%$ \\
\hline Berisiko & 18 & 30,0 \\
. Aman & 42 & 70,0 \\
\hline & & 100,0 \\
\hline
\end{tabular}

Distribusi Frekuensi Lingkungan Fisik

Tabel 3. Distribusi Frekuensi Lingkungan

Fisik Responden

Variabel Lingkungan Frekuensi \%

Fisik

( $\mathrm{n}=60)$

Dinding Rumah

. Kayu/Bambu

. Tembok

$\begin{array}{ll}10 & 16,7\end{array}$

$50 \quad 83,3$

Lantai Rumah

. Tanah

. Semen/Keramik

23,3

5896,7

100,0

Jendela Rumah

. Tidak ada

$10 \quad 16,7$

Ada

$50 \quad 83,3$

Ventilasi Rumah

Tidak ada

Ada

$\begin{array}{ll}4 & 6,7\end{array}$

$56 \quad 93,3$

Langit-langit

Tidak ada

100,0

Ada

$8 \quad 13,3$

5286,7

Genteng Kaca

\begin{tabular}{lll} 
Tidak ada & 25 & 41,7 \\
\hline
\end{tabular}

Ada

$35 \quad 58,3$

Tempat Sampah

- Tidak punya

. Terbuka

. Tertutup

$5 \quad 8,3$

5286,7

$3 \quad 5,0$

100,0

Tabel 4. Lanjutan Distribusi Frekuensi Lingkungan Fisik Responden

Variabel Lingkungan Frekuensi \%

Fisik

( $\mathrm{n}=60)$

Kondisi Saluran Air

. Tidak Mengalir

. Mengalir

23,3

\begin{tabular}{ll}
58 & 96,7 \\
\hline & 100,0
\end{tabular}

Penyimpanan Makanan

Terbuka

23,3

Tertutup

\begin{tabular}{lll}
\hline & 100,0 \\
\hline Tingkat Suhu & & \\
$\leq 28^{\circ} \mathrm{C}$ & 50 & 83,3 \\
$>28^{\circ} \mathrm{C}$ & 10 & 16,7 \\
\hline & & 100,0 \\
\hline Tingkat Pencahayaan & & \\
$<60$ lux & 39 & 65,0 \\
$\geq 60$ lux & 21 & 35,0 \\
\hline & & 100,0 \\
\hline Kelembaban & & \\
$61-90 \%$ & 18 & 30,0 \\
$31-60 \%$ & 41 & 68,3 \\
$\leq 30 \%$ & 1 & 1,7 \\
\hline & & 100 \\
\hline
\end{tabular}

Dinding Rumah Berhubungan dengan Indeks Pinjal Khusus

Tabel 5. Tabulasi Silang antara Jenis Dinding Rumah dengan Indeks Pinjal Khusus

Jenis Dinding Kategori IPK

Rumah $\quad$ Berisiko Aman

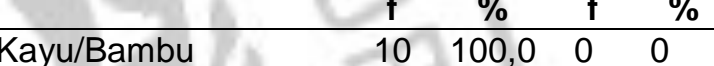

Tembok

$\begin{array}{llll}8 & 16,0 & 42 & 84,0\end{array}$

${ }^{*} \mathrm{p}=0,0$

Berdasarkan uji Fisher Exact, menunjukkan nilai singnifikansi $\mathrm{p}=0,00$ yang berarti $<0,05$, sehingga dapat disimpulkan bahwa $\mathrm{H} 0$ ditolak, yaitu terdapat hubungan antara kondisi dinding rumah dengan indeks pinjal khusus. Hasil penelitian ini sesuai dengan penelitian Evi Noerista Lestari (2017) yang menyatakan bahwa terdapat hubungan yang signifikan antara kondisi lingkungan dengan kepadatan tikus. Kepadatan tikus sendiri berhubungan langsung dengan kepadatan pinjal. ${ }^{6}$

Sebagian besar responden yang memiliki rumah dengan IPK tinggi menggunakan kayu/bambu sebagai dinding rumah. Di awal wabah Pes terjadi, penelitian dan pemeriksaan yang dilakukan oleh dr. Van Loghem menemukan bahwa kondisi perumahan penduduk yang kurang diperhatikan menjadi tempat bersarang tikus, termasuk penggunaan bambu dan kayu sebagai dinding. ${ }^{7}$

Jendela Rumah Berhubungan dengan Indeks Pinjal Khusus

Tabel 6. Tabulasi Silang antara Keberadaan Jendela Rumah dengan Indeks Pinjal Khusus

\begin{tabular}{ccccc}
\hline Keberadaan Jendela & \multicolumn{3}{c}{ Kategori IPK } \\
\cline { 2 - 4 } Rumah & \multicolumn{1}{c}{ Berisiko } & Aman \\
\cline { 2 - 4 } & f & $\%$ & f & $\%$ \\
\hline
\end{tabular}




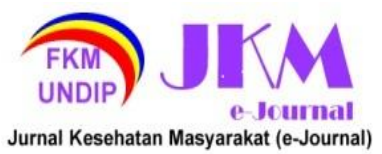

JURNAL KESEHATAN MASYARAKAT (e-Journal)

Volume 9, Nomor 6, November 2021

ISSN: 2715-5617 / e-ISSN: 2356-3346

http://ejournal3.undip.ac.id/index.php/jkm $\begin{array}{lllll}\text { Tidak ada } & 10 & 100,0 & 0 & 0\end{array}$

\begin{tabular}{lllll} 
Ada & 8 & 16,0 & 42 & 84,0 \\
\hline
\end{tabular}

${ }^{*} \mathrm{p}=0,0$

Tabel di atas menunjukkan bahwa rumah responden yang tidak berjendela memiliki indeks pinjal khusus lebih besar dibandingan rumah dengan jendela. Berdasarkan uji Fisher Exact, menunjukkan nilai signifikansi $\mathrm{p}=0,00$ yang berarti $<0,05$ sehingga dapat disimpulkan bahwa $\mathrm{HO}$ ditolak, yakni terdapat hubungan antara keberadaan jendela rumah dengan indeks pinjal khusus.

Hal ini didukung juga oleh penelitian Mulyati dan Baretelan (2011) bahwa kurangnya ventilasi dan jendela dapat mendukung frekuensi perkembangbiakan binatang pengerat, terutama tikus, ${ }^{8}$ yang berbanding lurus dengan IPK. ${ }^{3}$

Keberadaan jendela akan memengaruhi kondisi pencahayaan, suhu, dan kelembaban dalam rumah. Kondisi-kondisi tersebut akan berpengaruh terhadap kelangsungan hidup pinjal yang bersemayam dalam tikus-tikus rumah. Rumah yang memiliki jendela, memiliki risiko indeks pinjal khusus yang lebih rendah dibandingkan rumah tanpa jendela. ${ }^{8}$

\section{Langit-langit Rumah Berhubungan dengan Indeks Pinjal Khusus \\ Tabel 7.Tabulasi Silang antara Keberadaan Langit-langit Rumah dengan Indeks Pinjal Khusus}

\begin{tabular}{lllll}
\hline \multirow{2}{*}{$\begin{array}{l}\text { Keberadaan Langit- } \\
\text { langit Rumah }\end{array}$} & \multicolumn{4}{c}{ Kategori IPK } \\
\cline { 2 - 5 } & \multicolumn{3}{c}{ Berisiko } & \multicolumn{1}{c}{ Aman } \\
\cline { 2 - 5 } & f & $\%$ & f & $\%$ \\
\hline Tidak ada & 8 & 100,0 & 0 & 0 \\
Ada & 10 & 19,2 & 42 & 80,8 \\
\hline${ }^{*} \mathrm{p}=0,00$ & & & &
\end{tabular}

Tabel 6 menunjukkan bahwa rumah responden yang tidak menggunakan langitlangit memiliki indeks pinjal khusus lebih besar dibandingkan rumah dengan langit-langit. Berdasarkan uji Fisher Exact, menunjukkan nilai signifikansi $p=0,00$ yang berarti $<0,05$ sehingga dapat disimpulkan bahwa $\mathrm{HO}$ ditolak, yakni terdapat hubungan antara keberadaan langit-langit rumah dengan indeks pinjal khusus.

Sesuai dengan penelitian Arumsari, Sutiningsih, dan Hestiningsih (2012), bahwa keadaan lingkungan rumah yang kurang baik bahkan buruk sangat cocok untuk perkembangbiakan tikus, ${ }^{9}$ yang akan secara langsung berpengaruh terhadap kepadatan pinjal. $^{3}$ Sedangkan Dr. Swellengrebel secara spesifik menyebutkan bahwa kondisi langitlangit rumah, khususnya yang terbuat dari kayu, berkontribusi dalam hubungannya dengan keberadaan tikus dan hasil penangkapan pinjal. ${ }^{7}$

Di Surorowo sendiri, sebagian besar rumah telah memasang langit-langit berbahan plafon maupun sejenisnya (non kayu). Sedangkan rumah yang tidak memasang langit-langit, atau yang hanya menggunakan sekat kayu di atap, seluruhnya memiliki kepadatan pinjal berisiko. Bambu dan kayu tersebutlah yang menjadi tempat bersarang tikus dan kutu, khususnya yang berbentuk horizontal seperti di atap bagian dalam rumah. $^{7}$

Tingkat Suhu Berhubungan dengan Indeks Pinjal Khusus

Tabel 8. Tabulasi Silang Antara Tingkat Suhu dengan Indeks Pinjal Khusus

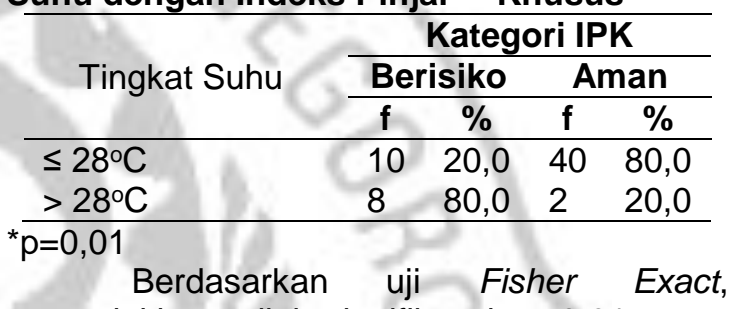
menunjukkan nilai signifikansi $p=0,01$ yang berarti < 0,05 sehingga dapat disimpulkan bahwa HO ditolak, yaitu terdapat hubungan antara tingkat suhu dengan indeks pinjal khusus.

Hal ini sesuai dengan penelitian Supriyati dan Ustiawan (2013) yang menyatakan bahwa suhu memengaruhi perkembangan tikus, yang juga berpengaruh terhadap kepadatan pinjal. ${ }^{10} \mathrm{Hal}$ ini sejalan juga dengan penelitian Mukono (2000) yang menyatakan bahwa suhu yang tidak optimal memiliki hubungan yang tidak menguntungkan bagi kelangsungan hidup pinjal. ${ }^{11}$

Dusun Surorowo yang berada di deretan pegunungan Tengger Bromo Semeru memiliki suhu dingin dengan udara kering, hal ini sangat mendukung kelangsungan hidup pinjal. Dari hasil penelitian, $80 \%$ rumah responden memiliki suhu dalam ruang yang mendukung perkembangan, yakni $>28^{\circ} \mathrm{C},{ }^{12}$ dan indeks pinjal khusus yang berisiko juga sebagian besar ada di kelompok rumah dengan suhu ruang tersebut.

Faktor Lingkungan Fisik yang Tidak Berhubungan dengan Indeks Pinjal Khusus Tabel 9. Tabulasi Silang Antara Lantai Rumah dengan Indeks Pinjal Khusus

\begin{tabular}{ll}
\hline \multirow{2}{*}{ Lantai Rumah } & \multicolumn{2}{c}{ Kategori IPK } \\
\cline { 2 - 3 } & Berisiko Aman \\
\hline
\end{tabular}




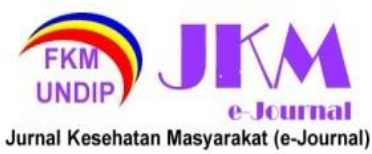

\begin{tabular}{lllll}
\hline & f & $\%$ & f & \multicolumn{1}{c}{$\%$} \\
\hline Tanah & 0 & 0,0 & 2 & 100,0 \\
Semen/keramik & 18 & 31,0 & 40 & 69,0 \\
\hline
\end{tabular}

${ }^{*} \mathrm{p}=1,00$

Berdasarkan uji Fisher Exact, menunjukkan nilai signifikansi $p=1,00$ yang berarti $>0,05$ sehingga dapat disimpulkan bahwa $\mathrm{HO}$ diterima, yaitu tidak terdapat hubungan antara kondisi lantai rumah dengan indeks pinjal khusus. Observasi Dr. Swellengrebel menyatakan bahwa fondasi dan lantai kayu biasa menjadi tempat bersembunyi tikus. ${ }^{7}$ Sedangkan di Surorowo tidak ditemukan rumah dengan lantai kayu, melainkan sebagian besar menggunakan semen/keramik, yang ternyata tidak menutup kemungkinan masih terjadinya lubang yang dapat menjadi jalan bagi tikus.

Tabel 10. Tabulasi Silang Antara Tingkat Pencahayaan dengan Indeks Pinjal Khusus

\begin{tabular}{lllll}
\hline \multirow{2}{*}{$\begin{array}{l}\text { Tingkat } \\
\text { Pencahayaan }\end{array}$} & \multicolumn{4}{l}{ Kategori IPK } \\
\cline { 2 - 5 } & \multicolumn{1}{l}{ Berisiko } & \multicolumn{2}{l}{ Aman } \\
\cline { 2 - 5 } & $\mathbf{f}$ & $\%$ & $\mathbf{f}$ & $\%$ \\
\hline$<60$ lux & 13 & 33,3 & 26 & 66,7 \\
$\geq 60$ lux & 5 & 23,8 & 16 & 76,2 \\
\hline $\mathrm{p}=0,560$ & & & &
\end{tabular}

Berdasarkan hasil penelitian, tingkat pencahayaan tidak berhubungan secara statistik dengan indeks pinjal khusus. Hal ini tidak sesuai dengan penelitian Ircham Machtoedz (2008) yang menyatakan bahwa penerangan yang cukup merupakan salah satu indikator rumah yang memenuhi sistem kesehatan lingkungan. Selain itu, kondisi yang gelap di dalam rumah juga dapat menghadirkan hewan pengerat, serangga, dan mikrobakteri lain yang berpotensi menimbulkan penyakit. ${ }^{13}$

Tidak adanya hubungan di antara keduanya dalam penelitian ini, karena letak uji tingkat pencahayaan dilakukan di ruang utama rumah, bukan di tempat trap dipasang. Faktor lain tidak adanya hubungan dimungkinkan karena pinjal pindah ke vektor lain saat di dalam live trap. Karena pinjal mendeteksi adanya cahaya, pinjal akan menghindari cahaya tersebut (fototaksis negatif). ${ }^{11}$

Tabel 11. Tabulasi Silang Antara Tingkat Kelembaban dengan Indeks Pinjal Khusus

\begin{tabular}{ccccc}
\hline \multirow{2}{*}{$\begin{array}{c}\text { Tingkat } \\
\text { Kelembaban }\end{array}$} & \multicolumn{4}{c}{ Kategori IPK } \\
\cline { 2 - 5 } & \multicolumn{3}{c}{ Berisiko } & \multicolumn{2}{c}{ Aman } \\
\cline { 2 - 5 } & $\mathbf{f}$ & $\%$ & $\mathbf{f}$ & $\%$ \\
\hline $61-90 \%$ & 7 & 38,9 & 11 & 61,1 \\
$31-60 \%$ & 11 & 26,8 & 30 & 73,2 \\
\hline
\end{tabular}

Volume 9, Nomor 6, November 2021

ISSN: 2715-5617 / e-ISSN: 2356-3346

http://ejournal3.undip.ac.id/index.php/jkm

\begin{tabular}{ccccc}
\hline$\leq 30 \%$ & 0 & 0,0 & 1 & 100,0 \\
${ }^{*} \mathrm{p}=0,290$ & Hasil & penelitian & menunjukkan & bahwa
\end{tabular}
tingkat kelembaban rumah tidak berhubungan secara statistik dengan IPK. Hasil ini tidak sesuai dengan penelitian Mulyati dan Baretelan (2011) yang menyebutkan bahwa kondisi ruangan rumah yang lembab juga mendukung perkembangbiakan tikus. ${ }^{8}$ Tikus berperan menjadi tempat bersarang pinjal pembawa bakteri penyebab pes. ${ }^{3}$

Ketidakberadaan hubungan antara kelembaban dan indeks pinjal khusus di desa Surorowo dimungkinkan karena pengukuran kelembaban menggunakan hygrometer dilakukan di ruangan utama, bukan di tempat dipasangnya trap, yaitu di tempat yang lebih dalam dan berkelok.

Tabel 12. Tabulasi Silang Antara Kondisi Tempat Sampah dengan Indeks Pinjal Khusus

\begin{tabular}{lcccc}
\hline \multirow{2}{*}{$\begin{array}{l}\text { Kondisi } \\
\text { Tempat Sampah }\end{array}$} & \multicolumn{4}{c}{ Kategori IPK } \\
\cline { 2 - 5 } & \multicolumn{1}{c}{ Berisiko } & \multicolumn{2}{c}{ Aman } \\
\cline { 2 - 5 } & f & $\%$ & f & $\%$ \\
\hline Terbuka & 15 & 28,8 & 37 & 71,2 \\
Tertutup & 1 & 33,3 & 2 & 66,7 \\
Tidak punya & 2 & 40,0 & 3 & 60,0 \\
\hline
\end{tabular}

${ }^{*} \mathrm{p}=0,409$

Hasil penelitian menunjukkan tidak adanya hubungan secara statistik antara kondisi tempat sampah dan indeks pinjal khusus. Hal ini tidak didukung oleh penelitian Mulyati dan Baretelan (2011) yang menyatakan bahwa kondisi lingkungan di rumah yang bersampah akan mendukung perkembangbiakan tikus, ${ }^{8}$ yang memengaruhi kepadatan pinjal. $^{3}$

Tidak adanya hubungan antara kondisi tempat sampah dengan indeks pinjal khusus dimungkinkan karena sebagian besar masyarakat Surorowo menggunakan tempat terbuka untuk membuang sampah. Tempat terbuka yang dimaksud adalah tebing-tebing di perbukitan samping rumah. Karena sudah tidak berada di lingkungan rumah, hal ini tentu berkontribusi terhadap ketidakberadaan hubungan antara tempat sampah dengan indeks pinjal khusus, yang dihitung di lingkungan rumah penduduk.

Tabel 13. Tabulasi Silang Antara Penutup Saluran Air dengan Indeks Pinjal Khusus

\begin{tabular}{ccccc}
\hline \multirow{2}{*}{$\begin{array}{c}\text { Penutup } \\
\text { Saluran Air }\end{array}$} & \multicolumn{3}{c}{ Kategori IPK } \\
\cline { 2 - 5 } & \multicolumn{2}{c}{ Berisiko } & \multicolumn{2}{c}{ Aman } \\
\cline { 2 - 5 } & $\mathbf{f}$ & $\%$ & $\mathbf{f}$ & $\%$ \\
\hline Kayu/plastik & 16 & 30,8 & 36 & 69,2 \\
\hline
\end{tabular}




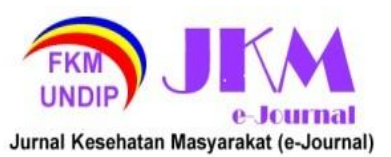

\begin{tabular}{lllll}
\hline Besi & 1 & 100,0 & 0 & 0 \\
Tidak ada & 1 & 14,3 & 6 & 85,7 \\
\hline
\end{tabular}

${ }^{*} \mathrm{p}=0,685$

Hal ini bertentangan dengan pernyataan Ircham Machtoez (2008) bahwa rumah yang memenuhi syarat kesehatan memiliki sistem kesehatan lingkungan, salah satunya merupakan saluran limbah dapur dan saluran air kamar mandi yang baik. Kondisi yang sesuai kesehatan lingkungan tersebut akan menghindarkan rumah dari serangga dan hewan pengerat. ${ }^{13}$ Dan akan berpengaruh pada rendahnya tingkat indeks pinjal. $^{3} \mathrm{Di}$ lapangan, hampir seluruh rumah menggunakan penutup saluran air berbahan kayu/plastik yang mudah ditembus tikus. Rumah dengan penutup berbahan besi justru memiliki indeks pinjal khusus yang tinggi. Hal ini dimungkinkan karena intensitas pemasangan penutup saluran yang jarang oleh pemilik rumah.

\section{KESIMPULAN}

Berdasarkan hasil penelitian mengenai faktor lingkungan yang berhubungan dengan indeks pinjal khusus di wilayah fokus Pes Dusun Surorowo, Kabupaten Pasuruan, dapat disimpulkan gambaran faktor lingkungan fisik sebagai berikut:

1. Terdapat hubungan antara jenis dinding rumah dengan indeks pinjal khusus di wilayah fokus Pes Dusun Surorowo

2. Terdapat hubungan antara keberadaan jendela dengan indeks pinjal khusus di wilayah fokus Pes Dusun Surorowo.

3. Terdapat hubungan antara keberadaan langit-langit rumah dengan indeks pinjal khusus di wilayah fokus Pes Dusun Surorowo.

4. Terdapat hubungan antara tingkat suhu di rumah dengan indeks pinjal khusus di wilayah fokus Pes Dusun Surorowo.

5. Tidak terdapat hubungan antara jenis lantai rumah dengan indeks pinjal khusus di wilayah fokus Pes Dusun Surorowo.

6. Tidak terdapat hubungan antara tingkat pencahayaan di rumah dengan indeks pinjal khusus di wilayah fokus Pes Dusun Surorowo.

7. Tidak terdapat hubungan antara tingkat kelembaban di rumah dengan indeks pinjal khusus di wilayah fokus Pes Dusun Surorowo.

8. Tidak terdapat hubungan antara kondisi tempat sampah dengan indeks pinjal khusus di wilayah fokus Pes Dusun Surorowo.
9. Tidak terdapat hubungan antara jenis penutup saluran air dengan indeks pinjal khusus di wilayah fokus Pes Dusun Surorowo.

\section{SARAN}

Berdasarkan hasil penelitian di atas, untuk mengurangi risiko tingginya indeks pinjal khusus di Dusun Surorowo, masyarakat perlu mengurangi rongga di dinding yang dapat menjadi tempat hidup dan jalan bagi tikus. Selain itu, diperlukan pengadaan jendela untuk memastikan pencahayaan dan kelembaban yang bagus di dalam rumah, dan pengurangan sekat kayu di langit-langit rumah agar tidak menjadi jalan bagi tikus.

\section{DAFTAR PUSTAKA}

1. Ramadhani T. Rekonfirmasi Rattus sp. sebagai Reservoir Pes di Kabupaten Boyolali. Banjarnegara; 2010.

2. Wahyudi MA. Effect Of Climate And Sanitation Of Rats Population And Index Flea As Indicator Detection Yersinia pestis In Port Surabaya. Int J Sci Res Manag. 2016;

3. Direktorat Jenderal Pengendalian Penyakit dan Penyehatan Lingkungan. Petunjuk Teknis Pengendalian Pes. III. Jakarta: Kemenkes RI; 2014.

4. Rahmawati E. Partisipasi lbu dalam Pemasangan Live Trap terhadap Jumlah Tangkapan Tikus dan Pinjal di Desa Sukabumi Kecamatan Cepogo Kabupaten Boyolali. Unnes J Public Heal. 2013;

5. BBTKLPP Surabaya. Laporan Kegiatan Surveilans Pes. Pasuruan; 2017.

6. Lestari EN. Hubungan Perilaku Penduduk dan Lingkungan dengan Angka Kepadatan Tikus pada Daerah Fokus, Terancam, dan Aman Pes di Kecamatan Tutur Kabupaten Pasuruan 2016. Universitas Airlangga; 2017.

7. Luwis S. Pemberantasan Penyakit Pes di Malang 1911-1916. Universitas Indonesia; 2008.

8. Hubungan antara Sanitasi Rumah Warga dengan Jumlah Tikus dan Kepadatan Pinjal di Desa Selo Boyolali. Universitas Muhammadiiyah Surakarta; 2013.

9. Masyarakat JK. Analisis Faktor Lingkungan Abiotik yang Mempengaruhi Keberadaan Leptospirosis pada Tikus di Kelurahan Sambiroto, Kecamatan Tembalang, Kota Semarang. 2012;1.

10.Tikus S, Dan C, Yang P, Di D, Kota P, Supriyati D, et al. Spesies tikus, cecurut 


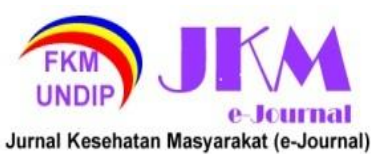

dan pinjal yang ditemukan di pasar kota banjarnegara, kabupaten banjarnegara tahun 2013 species rats, shrew and fleas found in the market town banjarnegara, banjarnegara district 2013. 2013;2013:3946.

11.Mukono HJ. Prinsip Dasar Kesehatan Lingkungan. Surabaya: Airlangga University Press; 2000.

12.Turner RW, Padmowirjono S MS. Dynamics of The Plague Transmission Cycle in Central Java (Ecology of mammalian host with special reference to Rattus exulans). Buli Penelit Kesehat. 1975;III:41-71.

13.Machfoedz I. Menjaga Kesehatan Rumah Dari Berbagai Penyakit. Yogyakarta: Fitramaya; 2008.
Volume 9, Nomor 6, November 2021

ISSN: 2715-5617 / e-ISSN: 2356-3346

http://ejournal3.undip.ac.id/index.php/jkm

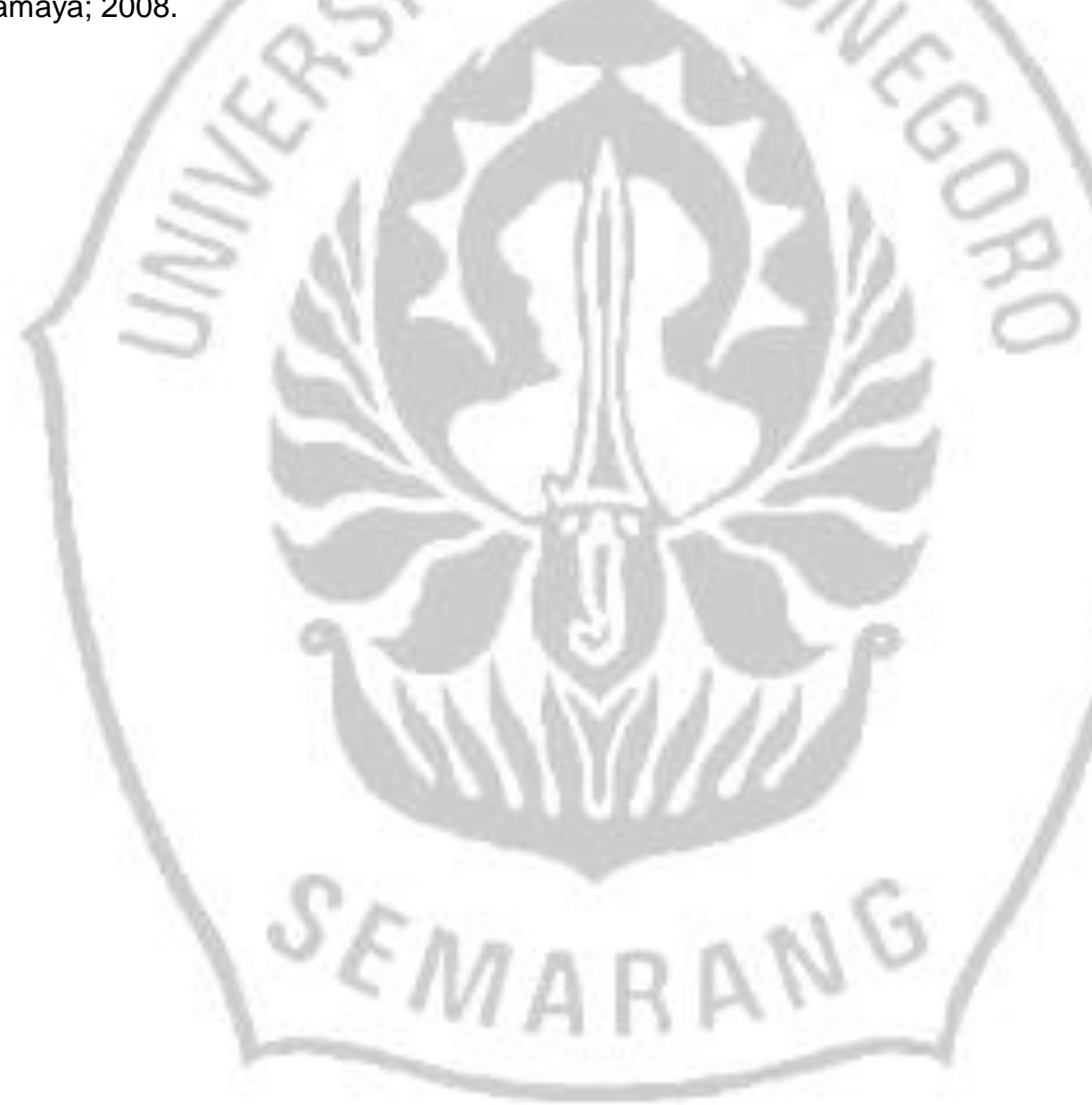

